\title{
AUTOMATIC CONFIGURATION OF MODULAR VAULT WALLS*
}

$U D C$ 692.21:004.92=111

\author{
Vladan Grković, Milan Kolarević, Miomir Vukićević, Mišo Bjelić \\ University of Kragujevac, Faculty of Mechanical Engineering Kraljevo, Serbia \\ kolarevic.m@mfkv.kg.ac.rs
}

\begin{abstract}
Products such as modular partition walls of vault rooms (with or without vault doors) are made at the request of the client who chooses the safety degree and provides the available dimensions of the wall that should be made. Modular construction of vault walls is the system of construction of industrially made elements which are composed in situ, which allows design of products adjusted to individual requirements of clients.

Since the vault wall modules repeat in every new project and since they differ only by their number and dimensions, the use of modern CA (Computer Aided) tools and the possibility of application of parameter and variant design shorten design time and eliminate possible errors in the process of design of modular vault walls, which reduces the costs of production and increases the level of product quality.

The paper presents the procedure for calculation of parameters of parts, modules and the entire vault wall in Microsoft Excel based on which the 3D model of a modular vault wall is automatically configured and developed in software package Autodesk Inventor.
\end{abstract}

Key words: vault wall, $3 D$ model, parameter modelling, variant design.

\section{INTRODUCTION}

The increased scope of valuables that should be safely deposited requires the space in which they can be safely kept. Instead of individual keeping, most owners of valuables entrust this job with the banks that possess vault room specifically designed for that purpose. The users of such vault room are:

- bank institutions, which keep there their money reserves in domestic and foreign currencies, reserves in precious metal and securities, but also their clients' valuables that are kept in vault rooms for renting,

- posts, for keeping cash and securities,

\footnotetext{
Received October 23, 2012

* Acknowledgements: The paper is a part of the research done within the project TR37020. The authors would like to thank the Ministry of Education and Science of the Republic of Serbia for supporting this research.
} 
- government and state authorities, as well as military and police organizations which use vault room for keeping confidential documents, bills, etc,

- industrial companies which usually keep there the objects connected with development of new products, procedures and services or documents connected with global operation of associations.

Vault rooms belong to complex and demanding construction-engineering facilities which should satisfy different, often confronted requirements. Their most significant required characteristic is that they should be safe from burglary. Fire safety, safety from different kinds of radiation as well as safety from flood, i.e. water penetration, which is difficult to achieve in practical construction, are not less important.

Since the classical way of construction of vault room is expensive and requires a lot of time, modular construction of vault room, which consists of industrially made elements, gains more and more significance. In the system of modular construction, individual modules are entirely made by the manufacturers of safety devices, and they are assembled in situ. The wall, floor and ceiling of modular vault room are, on average, two to five times thinner than the wall of vault room in mass construction. Proportionally, the masses (weights) of modular vault room are smaller.

The main advantages of the system of modular construction of vault room are [1]:

- thin walls which ensure large useful volume,

- the possibility of rearranging the already existing space into vault room and the possibility of placing vault room on higher floors of newly constructed buildings,

- modules of vault room are welded during installation, which provides compactness to the facility,

- very short time of construction of vault room, etc.

Every vault room essentially represents a new product which should be integrated into the dimensions set in advance. It requires repetition of all phases of the design process. Classical methods of modelling based on 2D modelling are rather slow and inevitably imply a series of errors in the design documentation, which is manifested in the process of construction of certain modules, and particularly in the process of assembling and mounting of the whole vault room.

The aim of this paper is to present the possibility of application of parameter and variant $3 \mathrm{D}$ modelling for automatic configuration of vault walls which are based on the modular structure for the purpose of fast response to individual requirements of clients and accomplishment of a high quality product.

\section{MODULAR VAULT ROOM AND WALLS}

\subsection{Types of vault room}

Vault room can be classified into the following categories:

- vault room in mass construction,

- vault room in modular construction, and

- vault room in combined construction. 
The characteristic of mass construction is that the concrete mixture is prepared on the site or near the site. As its name says, it looks robust. The wall, floor and ceiling of vault room are made of special concrete, in which the compressive strength must be high, but also achievable for every good construction company. Concrete possesses a large quantity of special fittings which improve anti-burglary properties of vault room and it is prepared on the site or in a workshop of the safety equipment manufacturer. The end part of the vault room in mass construction is the door of the vault room with the frame, which is also made by the safety equipment manufacturer.

Modular construction of vault room is the system of construction of industrially made elements, which are composed at the place of use. Individual modules (wall, floor and ceiling) are entirely made by the safety equipment manufacturer; they are then transported to the place of use and in a short period of time they are assembled into a vault room. Like in mass construction, the end part of vault room is the door of vault room with the frame, which is also made by the safety equipment manufacturer and it is usually the same as in mass construction.

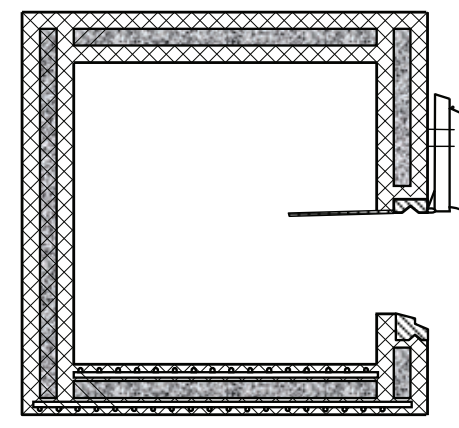

a)

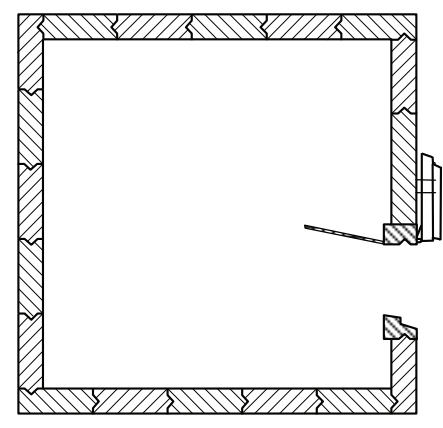

b)

Fig. 1. Schematic presentation of the horizontal section of vault room a) in mass construction, b) in modular construction [1]

Vault room in combined construction represents a combination of mass and modular construction (Fig. 2).

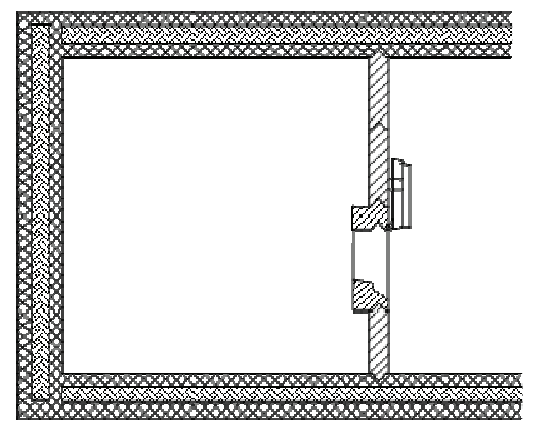

Fig. 2. Schematic presentation of the horizontal section of vault room in combined construction [1] 


\subsection{Modular vault wall}

The modular vault wall is formed of modules, types A, E and F. The constituent part of the vault wall can also be the vault door which is ordered independently of the wall. The appearance of the modular vault wall and the accompanying modules is shown in Figure 3.

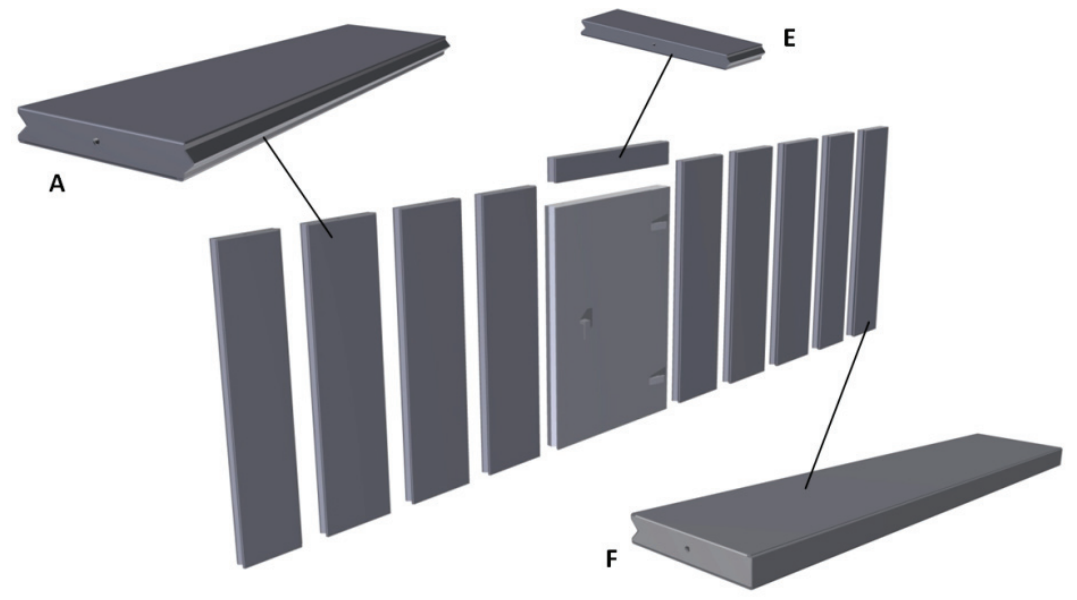

Fig. 3. Presentation of the disassembled partition wall with the vault door and the accompanying modules

The individual modules are composed of a metal frame (lamella) and a filling of special material. The structural scheme of the lamella type A is presented in Figure 4.

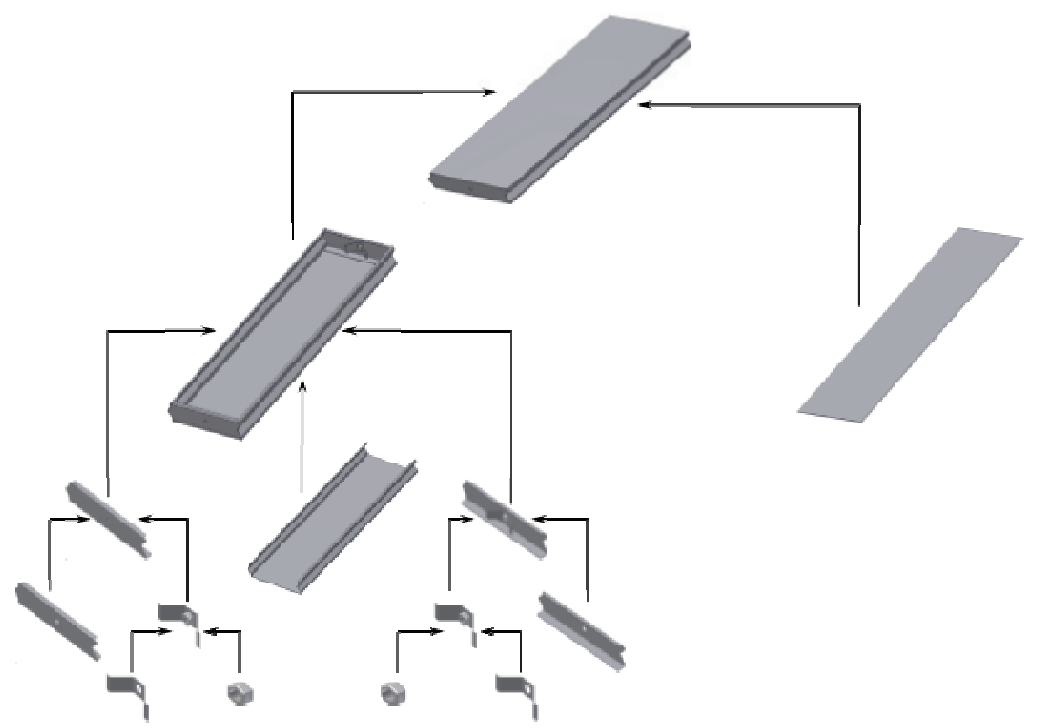

Fig. 4. Structural scheme of the lamella type A. 


\section{CONFIGURATION OF THE VAULT WALL}

In the process of manufacturing a modular vault wall, there is a series of technical restrictions that should be respected:

- technologically, it is not possible to make a lamella longer than $6000 \mathrm{~mm}$. For such cases, the vault room is made with a special understructure and lamellas that can be joined,

- the vault door cannot be longer than the height of the partition wall,

- the minimum distance between the vault door and the ends of the vault wall cannot be less than $400 \mathrm{~mm}$,

- the lamella width should be in the range $400 \mathrm{~mm} \leq \mathrm{b} \leq 850 \mathrm{~mm}$, where the standard width of the lamella is $b=550 \mathrm{~mm}$, the minimum lamella width is bmin $=400 \mathrm{~mm}$, and the maximum lamella width is bmax $=850 \mathrm{~mm}$. The lamellas which have a non-standard width are additionally denoted, for example, A1, A2, etc.

\subsection{Configuration procedure}

The procedure of forming (configuration) the modular partition wall with the vault door is shown in Figure 5. The modules are joined by welding. The sequence of configuration is as follows:

- the side to the left of the door is formed first. The initial lamella is A1 (the lamella A has a non-standard width), and then the necessary number of standard lamellas type A are placed next to it,

- the next segment to form is the vault door with the lamella E,

- the segment to the right of the door - which consists of the necessary number of standard lamellas type A, the non-standard lamella A2 (if necessary) and the lamella type $\mathrm{F}$ which comes at the right end of the wall - is formed at the end.

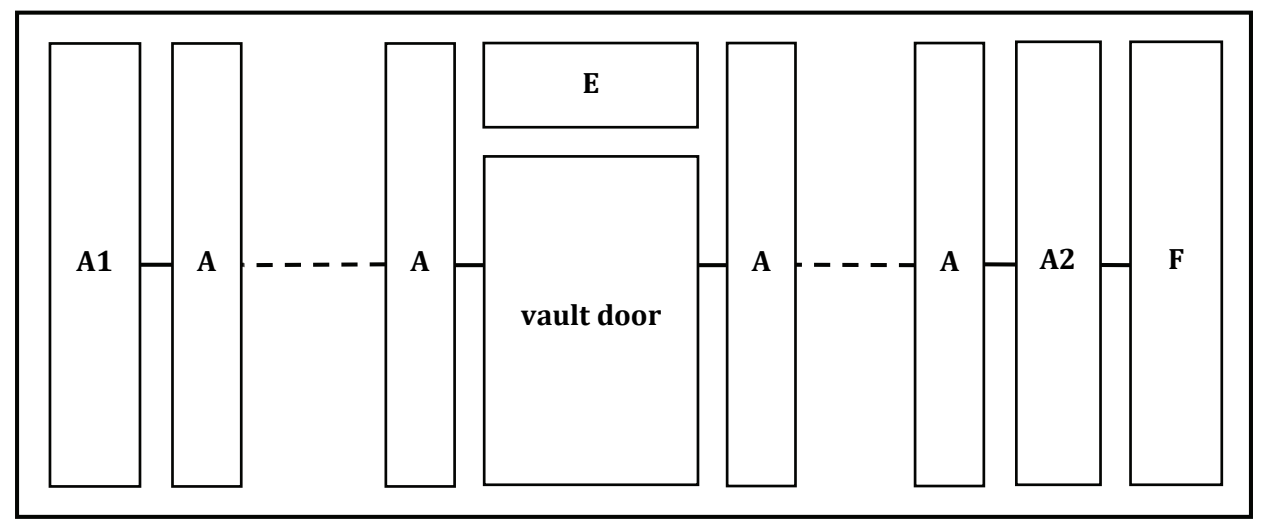

Fig. 5. Scheme of the configuration procedure for a modular vault wall with the door

There is a multitude of combinations for configuration of the vault wall out of the available fund of modules. During the selection of a possible combination, it is necessary to take care of the following criteria:

- the minimum number of modules that are used for configuration of the vault wall, 
- the minimum number of modules with a non-standard width (A1 and A2),

- producibility.

The given dimensions are (see Fig. 6):

- $\mathrm{X}$ - the length of the vault wall,

- Y -the height of the vault wall,

- E - the width of the vault door,

- F - the height of the vault door,

- $\mathrm{D}$ - the distance between the vault door and the left edge of the vault wall.

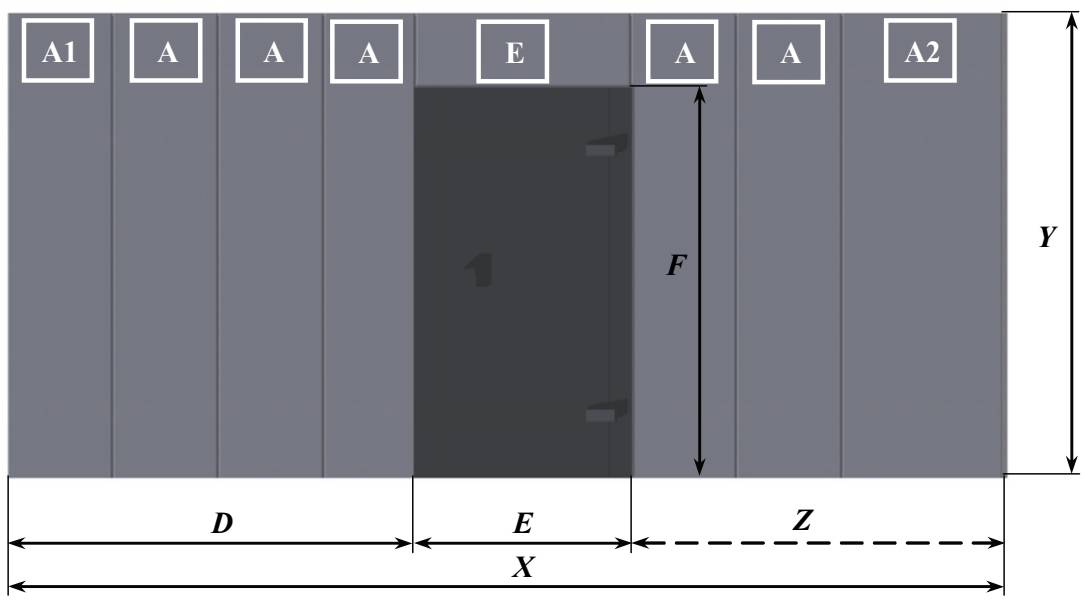

Fig. 6. Vault wall with the door and its main parameters and modules

For calculation of necessary parameters it is necessary to calculate the measure Z:

$$
Z=X-D-E
$$

and the additional parameters, $k$-the number of modules and $m$-the value of the rest (Table 1 ).

Table 1. Calculation of the parameters $k$ and $m$ :

\begin{tabular}{ccc}
\hline & Left of the door & Right of the door \\
\hline $\mathrm{k}, \mathrm{xx}=$ & $=\mathrm{D} / 550$ & $=\mathrm{Z} / 550$ \\
$\mathbf{k}$ & $=\mathrm{INT}(\mathrm{k}, \mathrm{xx})$ & $=\mathrm{INT}(\mathrm{k}, \mathrm{xx})$ \\
$\mathbf{m}$ & $=(\mathrm{k}, \mathrm{xx}-\mathrm{INT}(\mathrm{k})) * 550$ & $=(\mathrm{k}, \mathrm{xx}-\mathrm{INT}(\mathrm{k})) * 550$ \\
\hline
\end{tabular}

The combinations presented in Table 2 are those selected from possible combinations of modules during configuration of the partition wall to the left and right of the vault door.

\subsection{Calculation of parameters of the vault wall}

MS Excel was used for calculation of the parameters because of the simplicity of calculation, possibility of inserting logical functions and possibility for the software package Autodesk Inventor 2012 to import these parameters during product modelling. 
Table 2. Adopted patterns for calculation of the number and width of lamellas depending on the dimensions $\mathrm{D}$ and $\mathrm{Z}$

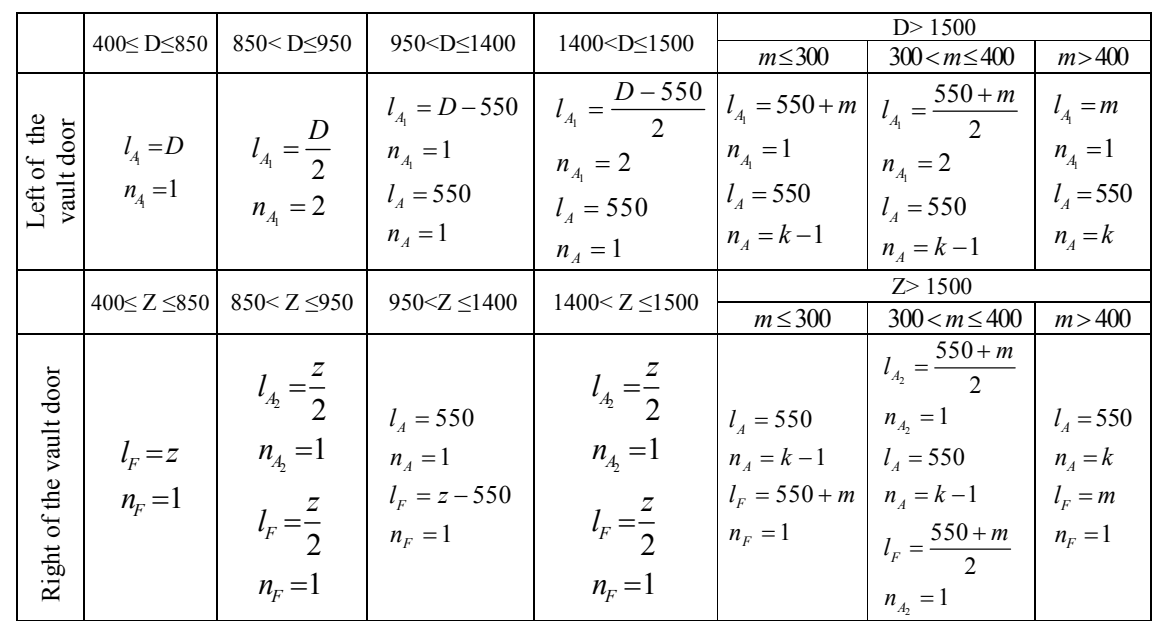

The process of calculating parameters is automated and reduced to entering the main dimensions of the partition wall, i.e. dimensions X, Y, D, E and F by the client, which is the basis for automatic calculation of the parameters necessary for modelling the modules $\mathrm{A}, \mathrm{A} 1, \mathrm{~A} 2, \mathrm{E}$ and $\mathrm{F}$ and the accompanying items.

The functions used for calculation of parameters are presented in Table 3.

\subsection{Automatic configuration of the vault wall}

All modules and items, which are constituent parts of the modules, are modelled by parameters in software package Autodesk Inventor 2012 (Figure 7). Parameter modelling is elaborated to the level of workshop drawings, and the values of parameters are automatically imported from MS Excel by software.

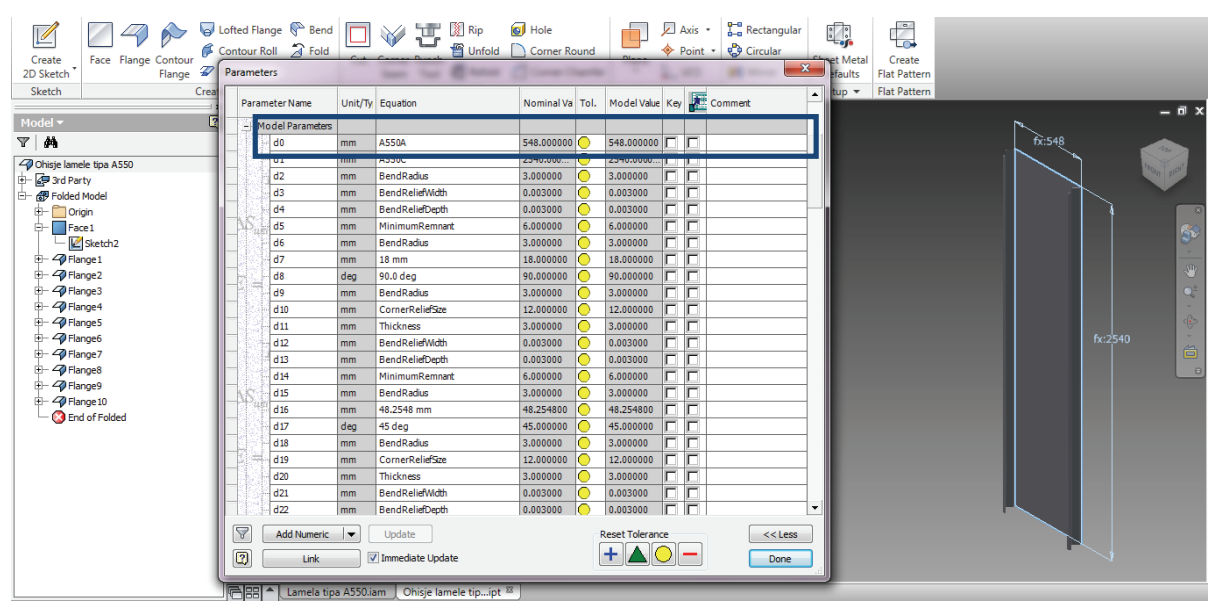

Fig. 7. Parameter modelling of the covering of lamella type A in Autodesk Inventor 
Table 3. Calculation of the width, length and necessary number of lamellas

\begin{tabular}{|c|c|c|c|c|c|c|c|c|c|c|}
\hline & \multicolumn{7}{|c|}{ SECTIOND } & \multirow{3}{*}{ EQUATION } \\
\hline & & & \multirow{2}{*}{$\begin{array}{l}0 \\
\text { on } \\
\text { vil } \\
\text { vil } \\
\text { ơ }\end{array}$} & \multirow{2}{*}{$\begin{array}{l}\text { o } \\
\text { Vh } \\
\text { v } \\
\text { ơ⿱口口 }\end{array}$} & \multirow{2}{*}{$\begin{array}{l}\text { ò } \\
\text { पे } \\
\text { v̀ } \\
\text { v } \\
\text { on }\end{array}$} & \multirow{2}{*}{ 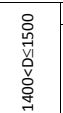 } & \multicolumn{3}{|c|}{$D>1500$} & \\
\hline & & & & & & & $\mathrm{m} \leq 300$ & $300<\mathrm{m} \leq 400$ & $m>400$ & \\
\hline \multirow{6}{*}{$\begin{array}{c}\text { LEFT OF } \\
\text { THE } \\
\text { DOOR }\end{array}$} & \multirow{3}{*}{ A1 } & $\begin{array}{l}\text { The width of } \\
\text { the lamella }\end{array}$ & $\mathrm{D}$ & $\mathrm{D} / 2$ & $\begin{array}{c}\text { D- } \\
550\end{array}$ & $\begin{array}{c}(\mathrm{D}- \\
550) / 2\end{array}$ & $550+m$ & $(550+m) / 2$ & $\mathrm{~m}$ & $\begin{array}{l}=\mid F(D \leq 850 ; D ; I F(D \leq 950 ; D / 2 ; I F(D \leq 1400 ; D-550 ; I F(D \leq 1500 ;(D-550) / 2 ; I F(m \leq 300 ; \\
550+m ; I F(m \leq 400 ;(550+m) / 2 ; m)))))\end{array}$ \\
\hline & & \begin{tabular}{|l}
$\begin{array}{l}\text { The lenght of } \\
\text { the lamella }\end{array}$ \\
\end{tabular} & \multicolumn{7}{|c|}{ Y } & $=Y$ \\
\hline & & $\begin{array}{l}\begin{array}{l}\text { The number of } \\
\text { the lamellas }\end{array} \\
\end{array}$ & 1 & 2 & 1 & 2 & 1 & 2 & 1 & 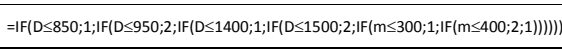 \\
\hline & \multirow{3}{*}{ A } & $\begin{array}{l}\text { The width of } \\
\text { the lamella }\end{array}$ & 550 & 550 & 550 & 550 & 550 & 550 & 550 & $=550$ \\
\hline & & $\begin{array}{l}\begin{array}{l}\text { The lenght of } \\
\text { the lamella }\end{array} \\
\end{array}$ & \multicolumn{7}{|c|}{$\mathrm{Y}$} & $=Y$ \\
\hline & & $\begin{array}{l}\text { The number of } \\
\text { the lamellas }\end{array}$ & 0 & 0 & 1 & 1 & $k-1$ & $k-1$ & k & $=I F(D \leq 950 ; 0 ; \mid F(D \leq 1500 ; 1 ; F(m \leq 400 ; k-1 ; k)))$ \\
\hline \multirow{4}{*}{$\begin{array}{l}\text { ABOVE } \\
\text { OF THE } \\
\text { DOOR }\end{array}$} & \multirow{4}{*}{ E } & The width of & \multirow{2}{*}{\multicolumn{7}{|c|}{$\mathrm{E}$}} & $=F$ \\
\hline & & \begin{tabular}{|l} 
the lamella \\
The lenght of
\end{tabular} & & & & & & & & \\
\hline & & the lamella & \multicolumn{7}{|c|}{$\mathrm{Y}-\mathrm{F}$} & $=Y-F$ \\
\hline & & $\begin{array}{l}\text { The number of } \\
\text { the lamellas }\end{array}$ & \multicolumn{7}{|c|}{1} & $=1$ \\
\hline & & \multirow[b]{3}{*}{ z } & \multicolumn{7}{|c|}{ SECTIONZ } & \multirow[b]{3}{*}{ EQUATION } \\
\hline & & & \multirow[b]{2}{*}{ 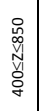 } & \multirow[b]{2}{*}{ 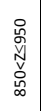 } & \multirow[b]{2}{*}{ 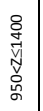 } & \multirow[b]{2}{*}{ 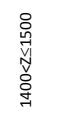 } & \multicolumn{3}{|c|}{$z>1500$} & \\
\hline & & & & & & & $\mathrm{m} \leq 300$ & $300<m \leq 400$ & $m>400$ & \\
\hline \multirow{9}{*}{$\begin{array}{l}\text { RIGHT } \\
\text { OF THE } \\
\text { DOOR }\end{array}$} & \multirow{3}{*}{ A } & $\begin{array}{l}\text { The width of } \\
\text { the lamella } \\
\end{array}$ & 550 & 550 & 550 & 550 & 550 & 550 & 550 & $=550$ \\
\hline & & $\begin{array}{l}\text { The lenght of } \\
\text { the lamella }\end{array}$ & \multicolumn{7}{|c|}{$\mathrm{Y}$} & $=Y$ \\
\hline & & $\begin{array}{l}\text { The number of } \\
\text { the lamellas }\end{array}$ & 0 & 0 & 1 & 0 & $k-1$ & $k-2$ & k & $=\mid F(Z \leq 950 ; 0 ; \mid F(Z \leq 1400 ; 1 ; \mid F(Z<1500 ; 0 ; \mid F(m \leq 300 ; k-1 ; \mid F(m \leq 400 ; k-1 ; k))))$ \\
\hline & \multirow{3}{*}{ A2 } & $\begin{array}{l}\begin{array}{l}\text { The width of } \\
\text { the lamella }\end{array} \\
\end{array}$ & 0 & $\mathrm{z} / 2$ & 0 & $z / 2$ & 0 & $(550+m) / 2$ & 0 & $\begin{array}{l}=I F(Z \leq 850 ; 0 ; I F(Z \leq 950 ; Z / 2 ; I F(Z \leq 1400 ; 0 ; I F(Z \leq 1500 ; Z / 2 ; I F(m \leq 300 ; 0 ; I F(m \leq 400 ; \\
(550+m) / 2 ; 0)))))\end{array}$ \\
\hline & & $\begin{array}{l}\begin{array}{l}\text { The lenght of } \\
\text { the lamella }\end{array} \\
\end{array}$ & \multicolumn{7}{|c|}{ Y } & $\mathrm{C}^{2}$ \\
\hline & & $\begin{array}{l}\text { The number of } \\
\text { the lamellas }\end{array}$ & 0 & 1 & 0 & 1 & 0 & 2 & 0 & $=\mid F(Z \leq 850 ; 0 ; \mid F(Z \leq 950 ; 1 ; \mid F(Z \leq 1400 ; 0 ; \mid F(Z \leq 1500 ; 1 ; \mid F(m \leq 300 ; 0 ; \mid F(m \leq 400 ; 1 ; 0)))))$ \\
\hline & \multirow{3}{*}{$\mathrm{F}$} & $\begin{array}{l}\text { The width of } \\
\text { the lamella }\end{array}$ & z & $\mathrm{z} / 2$ & $\begin{array}{c}- \\
550\end{array}$ & $z / 2$ & $550+m$ & 550 & $\mathrm{~m}$ & 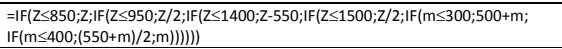 \\
\hline & & $\begin{array}{l}\text { The lenght of } \\
\text { the lamella }\end{array}$ & & & & & y & & & - \\
\hline & & $\begin{array}{l}\text { The number of } \\
\text { the lamellas }\end{array}$ & 1 & 1 & 1 & 1 & 1 & 1 & 1 & $=1$ \\
\hline
\end{tabular}

The advantages of variant design were used for automatic configuration of the modular vault wall. The module type A1 is the reference module to which the necessary number of modules type A are joined, then the module $\mathrm{E}$ and the vault door to which the necessary number of standard lamellas type A, the necessary number of lamellas type A2 and lamella type F are joined. The necessary number of lamellas A, A1 and A2 as well as all joints between the lamellas are the parameters which are automatically imported from MS Excel. The mutual distance between all lamellas is $2 \mathrm{~mm}$. This distance is technologically necessary so that the modules could be joined by welding.

For special cases when the number of certain modules is $n_{i}=0$, it is necessary to exclude their visibility in software. For such cases, the programme code for hiding lamellas was created in Autodesk Inventor. Those cases are:

- when the door is $400 \div 850 \mathrm{~mm}$ distant from the left side and then there is only the lamella type A1 on the left side, while the lamellas A are excluded (programme code 1) and

- when the door is $400 \div 850 \mathrm{~mm}$ distant from the right side and then there is only the lamella type $\mathrm{F}$ to the right of the door, and the lamellas A and A2 (to the right from the door) are excluded (programme code 2). 
The programme code for excluding the unnecessary modules to the left of the vault door

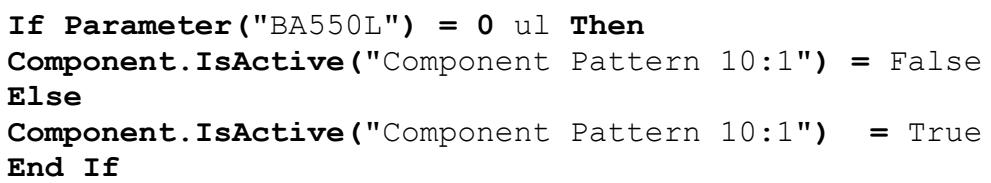

The programme code for excluding the unnecessary modules to the right of the vault door

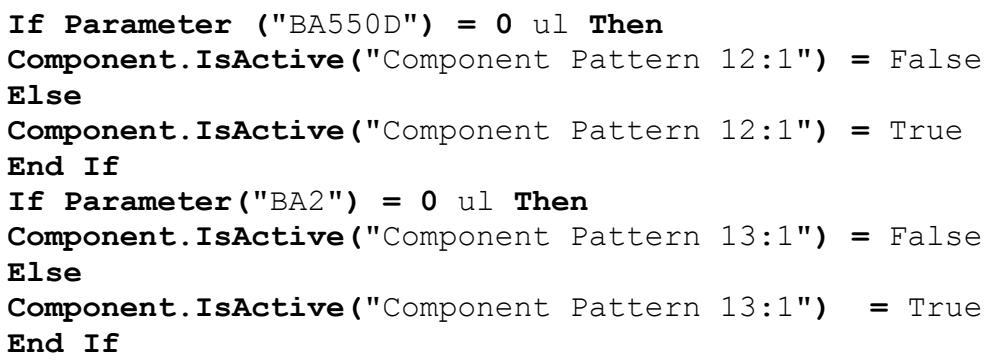

The appearance of the modular vault wall which is automatically configured after importing of parameters is presented in Figure 8.

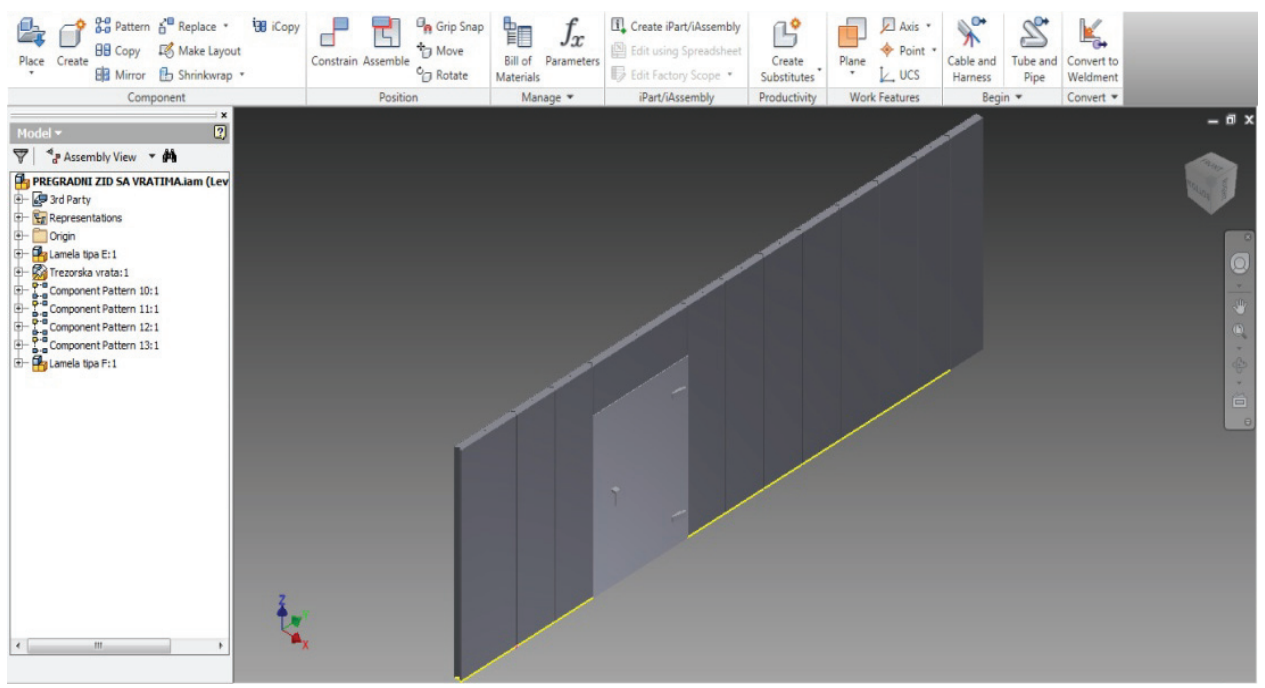

Fig. 8. Appearance of the modular vault wall configured in software package Autodesk Inventor 2012

\section{CONCLUSION}

Products such as modular vault walls are made at the request of the client who chooses the safety degree and provides available dimensions of the space in which such a product should be installed. The modular approach ensures the advantages of serial production 
and at the same time enables design of products adjusted to individual requirements of the client. However, every vault wall is a new project for which it is not possible to make a sample or prototype. The possibility of creating a virtual 3D model offered by modern software packages is very useful because the appearance of the vault wall and fitting of individual modules can be seen on the computer.

Since the modules of a vault wall repeat in every new project and since they differ only by their number and dimensions, the use of modern CA (Computer Aided) tools and the possibility of application of parameter and variant modelling allow full automation of the process of designing modular vault walls based on the previously adopted and defined platform.

This shortens design time, which is now several days, to less than 2 minutes necessary to enter geometrical data and allow the software to generate the $3 \mathrm{D}$ model of the vault wall, all modules and the accompanying elements to the level of workshop drawings. In addition, the design documentation obtained in this manner is of considerably better quality and without construction errors, which contributes to obtaining not only better quality production technology and good organization of production, but a quality product as well.

\section{REFERENCES}

1. Štefanec, E., Trezorski prostori, Narodna in univerzitetna Knjižnica Ljubljana, Maribor 2003.

2. Kolarević, M., Cvetković, LJ., Bošković, R., Parametric Modelling of Modular Vault Rooms, The Sixth Triennial International Conference Heavy Machinery HM 2008, Faculty of Mechanical Engineering, Proceedings, Kraljevo, pp. F13-F18, 24-29 June 2008.

3. Standard EN 1143-1, 2005.

\section{AUTOMATSKO KONFIGURISANJE MODULARNIH TREZORSKIH ZIDOVA}

\section{Vladan Grković, Milan Kolarević, Miomir Vukićević, Mišo Bjelić}

Proizvodi kao što su modularni pregradni zidovi trezorskih prostora (sa ili bez trezorskih vrata) rade se po zahtevu kupca koji bira stepen sigurnosti i daje raspoložive dimenzije zida koji je potrebno izraditi. Modularna gradnja trezorskih zidova je sistem gradnje od industrijski proizvedenih elemenata, koji se sastavljaju na mestu korišćenja čime se omogućuje konstruisanje proizvoda prilagođenih individualnim zahtevima kupca.

Sobzirom na to da se moduli trezorskog zida ponavljaju u svakom novom projektu i da se međusobno razlikuju samo po broju i dimenzijama, korišćenje savremenih CA (Computer Aided) alata i mogućnost primene parametarskog $i$ varijantnog projektovanja obezbeđuje skraćenje vremena projektovanja $i$ eliminisanje mogućih grešaka u procesu konstruisanja modularnih trezorskih zidova čime se smanjuju troškovi proizvodnje i povećava nivo kvaliteta proizvoda.

$U$ radu je prikazan postupak za izračunavanje parametara delova, modula i celog trezorskog zida $u$ Microsoft Excel-u na osnovu kojih se vrši automatsko konfigurisanje i formiranje 3D modela modularnog trezorskog zida u softverskom paketu Autodesk Inventor.

Ključne reči: trezorski zid, $3 D$ model, parametarsko modeliranje, varijantno projektovanje. 